\title{
Profile
}

\section{Thomas LaVeist: framing the debate on health disparities}

Thomas LaVeist tells me that it was a "somewhat embarrassing story" that explained how he eventually became one of the leading academics in the field of health and racial disparities in the USA. It was 1988 and he was at the University of Michigan working on his dissertation, which examined whether the political gains and election of African-Americans to local office during the 1980s had had an impact on quality of life overall. "I was kind of isolated and bored one day. Frankly, I was procrastinating so I took a walk." He wandered into a second-hand bookshop and found a book about the sinking of the Titanic in 1912. "That book talked about who survived the sinking of the Titanic as a function of the class of ticket they had", he said. "And it showed that women who had first-class tickets, almost all of them survived. But it you had a second- or third-class ticket, then your odds of surviving dramatically reduces." This was when LaVeist became "fascinated by the idea that sociological phenomena could actually be predictive of death", he said. "I found this to be a fascinating analogy for what I had begun to learn about health statistics, which was that your social status mattered quite a lot in terms of what your outcomes were. Up to that point, like most people, I thought that health care and biology were the primary determinants of how long you lived and what your quality of life was, what your quality of health was", he said.

LaVeist's dissertation led to the first of what would become a string of awards over the course of a career shaped by what he calls a sense of mission "to understand the question of why do we have inequalities in health outcomes and what can we do about it". He has been at Johns Hopkins University in Baltimore since 1990, where he is the William C and Nancy F Richardson Professor in Health Policy and Director of the Hopkins Center for Health Disparities Solutions at the Johns Hopkins Bloomberg School of Public Health. "The key finding of my research is that race inequalities in health result from the fact that the US remains a dramatically racially segregated country. While the nation's population is diverse, our communities are not", he said. "Health disparities are caused by social factors, not biology or health behaviour. When whites live in challenging social conditions (like black and Hispanic Americans typically do), the whites are just as unhealthy."

LaVeist's expertise in health and racial disparities has seen him give congressional testimony and write several books that have become standard textbooks on health disparities. He has even been approached by both the Democratic and Republican parties to stand for office, which he declined along with offers to join rival universities. David Williams, a public health professor at the Harvard School of Public Health, lauded LaVeist's contribution to the health disparities debate by drawing the attention of policy makers to the role of residential segregation on health. "Dr LaVeist is one of a handful of researchers who has done seminal research in the field of health disparities in the last two decades and has had a major influence on this area of research by raising awareness of the problem, addressing important research questions in the field, and pointing to interventions to reduce disparities," he said.

LaVeist grew up as one of four children in a housing project in Brownsville, Brooklyn. His mother immigrated from the Dominican Republic and his father from the Dutch-French island of St Martin. "All four of us have at least a master's degree so I think it says quite a lot about them as parents that they were able to produce children who've all been able to find a prominent place in this society", said LaVeist.

From his own prominent position, LaVeist has combined what he characterises as "out of the box questions"such as in the early 1990s examining the impact of black political gains on post-neonatal mortality-with conservative methods. "By conservative methods, I just mean that the study designs that I use are very traditional and well-established. I apply those methods to atypical research questions", he said. "That's been a very intentional strategy on my part." LaVeist's hope "to institutionalise the work so that it's lasting" seems to have been met, according to Amani Nuru-Jeter, a former doctoral student of his at Johns Hopkins and now Associate Professor in Community Health, Human Development and Epidemiology at the University of California, Berkeley. "He was asking questions before they became sexy and at that time it was risky but now they are valid areas of scientific enquiry", she said. "As a woman of colour, having an African-American to advise and to mentor me was great and he was a wonderful role model."

Taking stock of the US election last year, LaVeist said the re-election of President Barack Obama had safeguarded the implementation of the Patient Protection and Affordable Care Act. "This law has great promise to improve health equity. In addition to the expansion of access to health care, the community transformation grants attempt to address social determinants of health", he explained. "I think the major policy issues are to ensure funding and implementation of the law, nationalise efforts to require training in crosscultural communications among healthcare providers, and strengthening efforts to ensure health equity is accounted for within the regulatory agencies of the American health-care industry."

Sharmila Devi Rampeearee

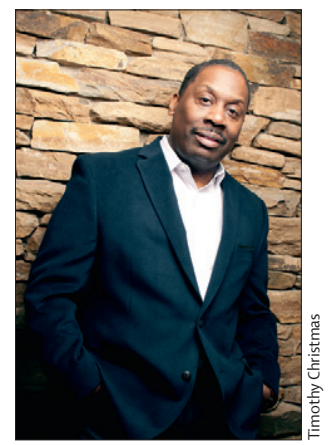

